\title{
An innovative approach on the renewable hybrid barrier: combined use of wood and sand
} Halil İbrahim Yumrutaș ${ }^{1 \mathrm{D}}$, Emre Birinci ${ }^{2 * i D}$, Hüseyin Yörür ${ }^{\text {iD }}$, Ali Osman Atahan ${ }^{3 i \mathrm{D}}$

'Karabuk University, Karabuk, Turkey

${ }^{2}$ Kastamonu University, Kastamonu, Turkey

${ }^{3}$ Istanbul Technical University, Istanbul, Turkey

\section{TECHNOLOGY OF FOREST PRODUCTS}

\begin{abstract}
Background: Wooden materials have been among the basic materials used in many different areas due to some advantages throughout the history. Roadside barriers, which are called passive safety structures, can be produced with different materials such as wood, steel, concrete, and plastic. In this study, Renewable Hybrid Barriers (RHB), a new type of barrier that is used wood in terms of aesthetics, renewability, high shock resistance, and used sand in terms of impact absorption capacity and low cost, produced by taking into account some of the disadvantages of other barrier types. These barriers are planned to be used especially in historical/touristic areas, scenic roads, and in urban areas as urban furniture. Real-time crash tests in accordance with EN 1317 (Road Restraint Systems) standard require high cost and long time. Therefore, the pendulum crash test mechanism frequently used in the literature was manufactured at which the experiments were carried out.
\end{abstract}

Results: The results revealed that the RHBs which has $2 \mathrm{~cm}$ thick timber and sand used together, were sufficient and suitable in terms of both cost and necessary safety criteria. It was observed that impregnation and heat treatment applications did not have a considerable negative effect on the performance of RHBs which provide an opportunity to use RHBs for outdoor conditions..

Conclusion: In the light of the results of the study, the optimum wood timber thickness was determined as $2 \mathrm{~cm}$ regarding TB 31 test criteria. It is proposed that the crash tests for different wood species, timber thickness, and/or barrier dimensions should carry out in future studies. This study can serve as the basis for the next step, real-time real crash tests. Since the study includes an interdisciplinary subject, it is thought that it will inspire different studies.

Keywords: Wooden barrier, Urban furniture, Sand, Hybrid, Crash pendulum

\section{HIGHLIGHTS}

Renewable hybrid barriers (RHBs) will reduce the severity of the damage that will occur after the crash. Optimum wood timber thickness that will be sufficient and suitable in terms of both cost and necessary safety criteria was determined as $2 \mathrm{~cm}$.

RHBs will create an added value by harmonizing with the landscape especially in historical/touristic areas, scenic roads, and in urban areas as urban furniture.

RHBs will be suitable for outdoor conditions and will contribute to reduce traffic noise.

YUMRUTAS, H. I.; BIRINCI, E.; YÖRÜR, H.; ATAHAN, A. O. An innovative approach on the renewable hybrid barrier: combined use of wood and sand. CERNE, v. 27, e-102821, doi: 10.1590/01047760202127012821 


\section{INTRODUCTION}

Humans used animals to move from one place to another about 4,000 years ago. After the invention of the wheel, the discovery of the wheeled wagons that increased mobility brought death and casualties with it. Traffic control services were first started by the Romans because of the arising primitive traffic density. (Davies, 2006; Kaszynski, 2012).

The World Health Organization estimates that an average of 1.2 million people die and 50 million are injured each year in traffic accidents. A total of 25,300 deaths were recorded in 10 million traffic accidents in Europe in 2017 (Chell et al., 2019; European Comission, 2018). In recent years, the concept of safety in traffic engineering has been classified as active and passive. The basic principle in active safety is to prevent the accident while the basic principle in passive safety is to minimize the probable damages due to any accident (Aashto, 2011; Ornek et al., 2019).

Passive safety structures, called as barrier and used at the edges and medians of highways, are designed to protect errant vehicles leaving road platform for any reason. The main purpose of the barriers is to reduce the severity of the accident and to minimize the damage caused by the accident rather than preventing the accident (Pilia et al., 2012). Barriers slow down errant vehicles and keep them on the road platform by absorbing some of the energy generated during the collision (Borovinsek et al., 2007; Elvik et al., 2009; Teng et al., 2016). An ideal barrier should direct the crash vehicle back towards the road at an acute angle for the safety of the road, passengers and other vehicles during the crash. Thus, the crashing vehicle follows the barrier line and is protected from situations that may cause negative consequences such as overturning and rolling over. It also reduces the risk of injury and death to the passengers inside the vehicle (Grzebieta et al., 2005).

Researchers have developed different barrier types to withstand big impact loads that will arise during the collision but due to safety and structural requirements, aesthetic side of barriers are ignored. Engineers generally could not realize the effect of these structures on the landscape, especially in scenic roads and historical places. For this reason, a barrier type must be designed to meet the needs both in terms of aesthetic and safety. Various types of barriers are used in the literature, including concrete, steel, plastic, and wood. All barrier types have some advantages and disadvantages compared to others (Davids et al., 2006; Yeginobali et al., 2011). In general, because of the rigid structure of concrete barriers and the fact that steel barriers contain sharp surfaces, undesirable consequences occur in both vehicles and passengers at the time of collision.

As far the wooden barriers, generally three types of wooden barriers are emphasized in the literature. One of these wooden barriers was constructed with wood material as, the main body and steel as the post of it while the other one was built the other way around. Another one was constructed with all wood material in all parts of the barrier. In the Fig. 1, some examples of wooden barriers from different countries are presented. There is not such a study evaluating the composite usage of wood and sand together, considering impact energy absorbing capability, traffic noise absorbing capability, traffic light absorbing capability and aesthetic side (Yumrutas and Yorur, 2017). Due to their aesthetic appearance, wooden barriers are generally applied in urban roads, mountainous and scenic roads, historical places, and for landscape design. Additionally, wooden barriers can be preferred on coastal roads due to their corrosion resistance instead of steel barriers.

In this study, a new barrier is called "renewable hybrid barrier" (RHB) has been designed and constructed with wood material and sand considering the disadvantages of other barrier types. In this context, the aesthetic apperance, renewability, ability to absorb impact energy and traffic noise and capability of impact energy absorption and cost-reducing effect of sand material of RHBs were all evaluated together. In the scope of the study, the effect of impregnation and heat treatment applied to wood materials constructed on the barriers on crash performance was examined. The produced RHBs were subjected to crash tests using the pendulum system specially designed for this study. The data obtained from the crash tests were evaluated according to the EN 1317 (Road Restraint Systems) standard and the behaviours during the collision was analysed.

\section{MATERIAL AND METHODS}

\section{Renewable Hybrid Barrier (RHB)}

RHBs aroseconsidering the advantages of wooden material such as aesthetic appearance, impact energy absorbing capability and traffic noise absorbing capability, being a renewable material, and also success in cost reduction and impact energy absorbing of sand together. It is a new generation barrier type that is used together with wood material and sand and is not included in the literature. Additionally, in the design, plant soil on the top of the RHB is placed to grow plants that can remain green for four seasons. Thereby it is aimed to improve the aesthetic appearance much more and to reduce the glare problem caused by oncoming traffic especially during night driving. Fig. 2 shows a visual of RHB. The primary goal of the RHB design process is to absorb the impact energy and to keep the crashing vehicle on road platform. In this study, RHBs are designed in concrete F-shape type barrier dimensions in order to compare with an existing barrier type used in the application and thus to prove the efficiency. It is thought that different designs can be created after optimization. RHBs consist of four main elements: concrete base, metal profiles, sand and timber. The main body of RHBs is formed by fixing metal profiles on the concrete baseand then the inner part of the barrier is filled with sandbags and the outer part is covered with timbers.

\section{Concrete Base}

Since RHBs had a wooden frame to prevent the wood material from the contacting the water in road platform in the long term, especially in rainy outdoor environments. For this reason, concrete bases were built in the given dimensions in Fig. 3. In addition, the connection of concrete bases with female and male parts allowed them to act together by helping energy transfer at the moment of a collision. 

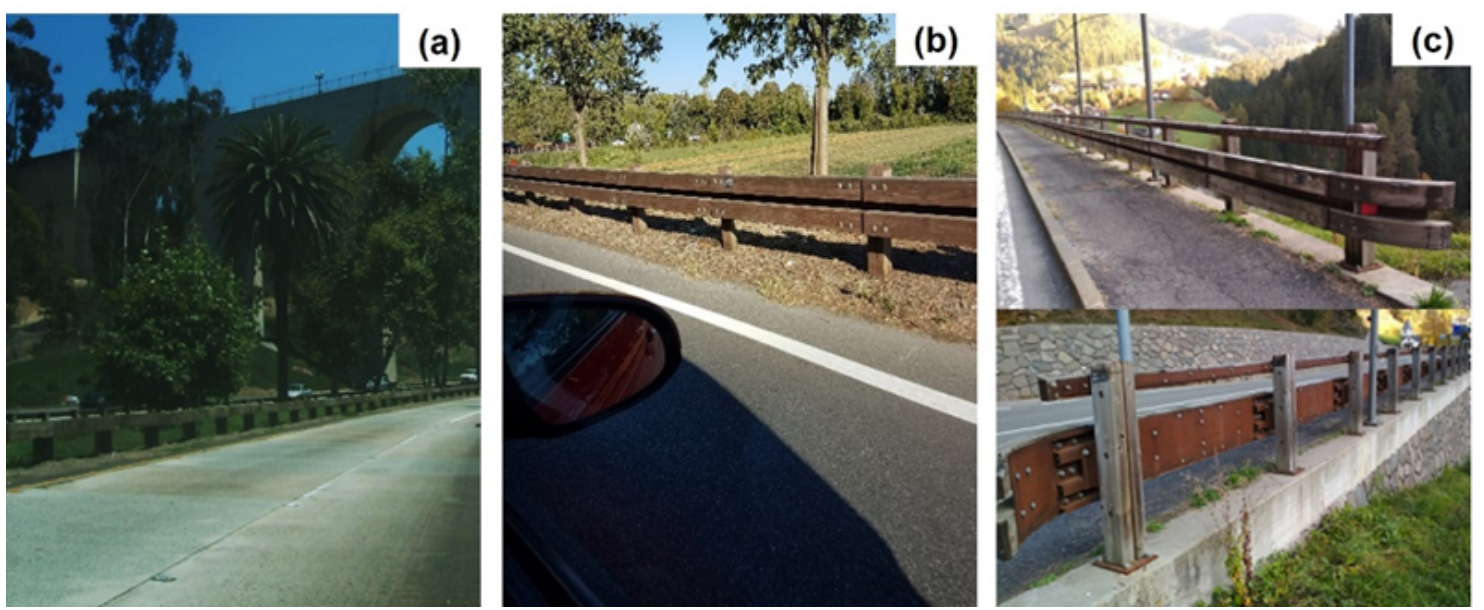

Fig. 1 Wooden barrier sample in the USA (a), Steel reinforced wooden barrier sample in Italy (b). Semi-wooden and semimetal barrier sample in Italy (c).

(a)

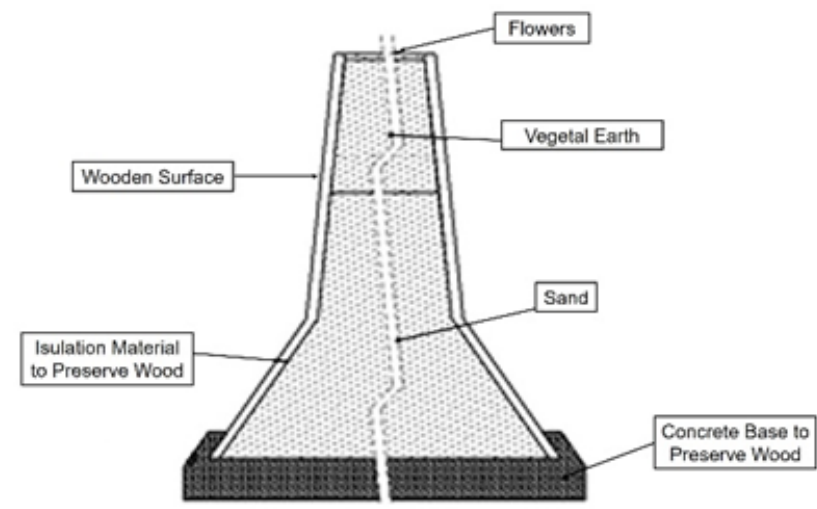

Fig. 2 Parts of RHB (a), Appearance of RHB on road platform (b).

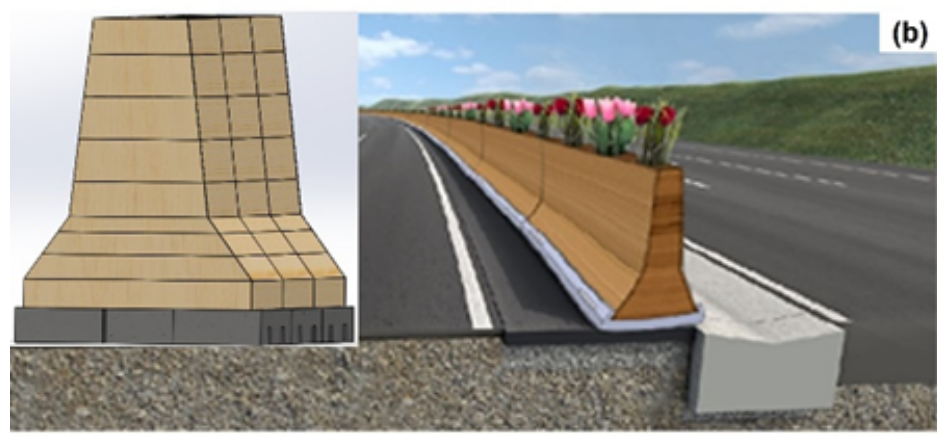

\section{Sand}

Sand was a soil material which had natural, granular, and elastoplastic features, and consisted of crushed rock and mineral particles with a diameter ranging from 0.075 $\mathrm{mm}$ to $2 \mathrm{~mm}$ and with a density between $1.5-1.80 \mathrm{ton} / \mathrm{m}^{3}$. It is cohesionless when dry or saturated with water, but with optimum water content, it has a certain cohesion (Poran and Rodriguez, 1992). In the production of RHB, crushed stone sand with a diameter of $0-5 \mathrm{~mm}$, which is widely used, is used. Studies in the literature support that sand has a high level of ability to absorb impact energy (Bhatti, 2015; Chian et al., 2017; Sabet et al., 2009; Ho and Masuya, 2013). The saturated sand is also taken into account in experimenta crashes of RHBs considering for outdoor applications. Besides, the sand material was placed in sandbags to prevent sand scattering on the platform in experimental crashes after the collision. This is related to real accident situation on the roads not to cause other accidents because of scattered sand.

\section{Steel Profiles}

Steel profiles were the elements that form the basic shape of the barrier and allowed the assembly of wooden timbers on which constructed horizontally to metal profiles via screws. Metal profiles were produced in the F-shape barrier form using $3 \mathrm{~mm}$ in thickness and 20x40 


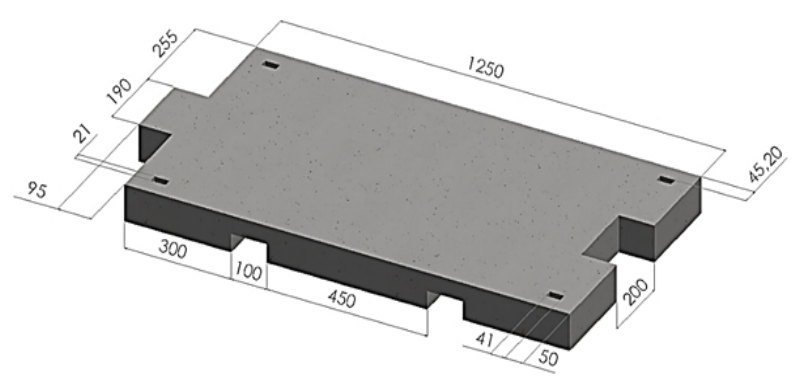

Fig. 3 Concrete base dimensions ( $\mathrm{mm}$ )

$\mathrm{mm}$ dimensions box profiles. They were mounted to the concrete base through the holes on the base. Connection points were fixed by welding. Two metal profiles were produced for each RHB. Their dimensions and an example are shown in Fig. 4a. It is planned to use three RHBs together in experimental crashes. Accordingly, in addition to connecting adjacent barriers by means of male and female parts of the concrete bases, each metal profile was connected to each other from four different points with the help of rod and nut in metric 12 dimensions (Figure 4b,c). By this way, it is aimed to distribute the energy that will emerge at the moment of any collision, among the entire barrier line rather than a single point.

\section{Timber}

Timber was the primary material that ensured the integrity and crash resistance of RHBs. In addition to being a renewable and environmentally friendly material providing an aesthetic appearance. It has many advantages such as easy workability, being paintable and varnishable, high carbon stock capacity, high strength compared to its density, high shock absorption, heat and sound insulation. (Birinci et al., 2021; Kollmann and Kuenzi, 1968; Parobek et al., 2019; Tudor et al., 2020; Yang et al., 2019; Zhang et al., 2020).

The cost of RHBs varied depending on the wood type and thickness. Therefore, fir (Abies nordmanniana subsp. Equi-trojani) timber was preferred for RHB production due to its easy availability in Turkey and its lower cost compared to other wood species.

Rubbed joining technique was applied to mount fir timbers on RHBs to prevent visual pollution and deformations that may occur in the joints due to shrink and swelling cycles and of fir timbers over time. Fir timbers were prepared 20 and $40 \mathrm{~mm}$ in thickness, $1250 \mathrm{~mm}$ in length, and $100 \mathrm{~mm}$ in width. Fir timbers were mounted onto metal profiles by using $3.5 \mathrm{~mm}$ diameter screws. In the literature, it is stated that for the efficiency of screwing quality, pilot holes should be drilled up to $80 \%$ of the screw diameter (Tor et al., 2020; Yorur et al. 2020). In accordance with the literature, pilot holes up to $80 \%$ of the screw diameter were drilled on the fir timbers before the screwing process. Four screws were used for fixing each timber and 72 screws in total were used for each RHB. In addition to the thickness of the wood material, the effect of impregnation and heat treatment applied to wood materials on the crash performance of RHBs was also examined. Accordingly, pendulum crash tests were carried out for RHBs produced using impregnated and heat-treated wood materials.

The impregnation process was carried out using Tanalith-E substance in a private forest products company. In the impregnation process, after the timbers were placed into the impregnation tank, they were subjected to a prevacuum process of $600 \mathrm{~mm} \mathrm{Hg}$ for 25 minutes. After the pre-vacuum process, the vacuum in the impregnation tank was discharged and Tanalith-E substance was added into the impregnation tank. After this process, a pressure of 12 bars was applied to the timbers for 30 minutes to increase the penetration of the impregnating material. At the end of the period, the pressure in the boiler was stopped and the Tanalith-E substance was removed from the impregnation tank. Finally, a second vacuum of $600 \mathrm{~mm} \mathrm{Hg}$ was applied for 20 minutes to remove the residual impregnating material on the timbers. After the impregnation process, the samples were conditioned at $22 \pm 3{ }^{\circ} \mathrm{C}$ and $65 \%$ relative humidity for 10 days in order to perform the fixation procedures.

Fir timbers were heat-treated in an industrial boiler at $110{ }^{\circ} \mathrm{C}$ under atmospheric pressure for seven hours. After the heat treatment, all samples were conditioned for 7 days at $20 \pm 2{ }^{\circ} \mathrm{C}$ room temperature and $65 \pm 5 \%$ relative humidity. In Fig.5, non-treated, impregnated, and heattreated fir timber samples are shown, respectively.

\section{EN1317 Standard Criteria}

It is regarded that RHBs designed in this study will be used on historical, touristic, and scenic roads where traffic volume and speed will be low and heavy vehicle traffic will be less. The crash test criteria are specified in the EN 1317 standard depending on the vehicle type, weight, collision speed and angle. Thus, it was decided that the RHBs would be in normal containment level (N1) and TB31 acceptance test would be suitable and the experiments were carried out in this direction.

According to EN 1317, the working width (W) is described as "the lateral distance between any part of the barrier on the undeformed traffic side and the maximum
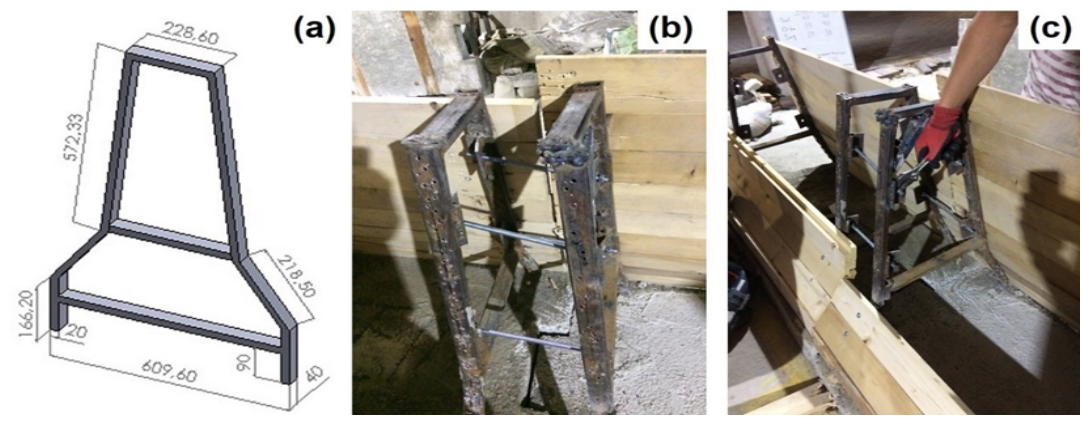

Fig. 4 Metal profile dimensions used in the production of RHBs $(\mathrm{mm})(\mathrm{a})$, Connection points of RHBs $(b, c)$. 
dynamic position of any part of the barrier" and the ASI (acceleration severity index) is described as "measure of the severity of the motion for a person within a vehicle during an impact with a road restraint system". Increasing the working width class indicates the rigidity of the barriers, and the decrease indicates the flexibility. The ASI value is accepted as an indicator of the magnitude of passenger injuries in the vehicle due to collision to any obstacles. (Danek and Pawlak, 2018). According to EN 1317, ASI value is classified as $\mathrm{A}(\leq 1.0), \mathrm{B}(\leq 1.4)$ and $\mathrm{C}(\leq 1.9)$. When these values are exceeded, this means that there is a risk in terms of passenger safety. ASI value is calculated according to the equation shown in Formula 1. In this formula, ASI: acceleration severity index, $\bar{a}_{\mathrm{x}}(\mathrm{t})$ : maximum acceleration in $\mathrm{x}$ direction $\left(\mathrm{m} / \mathrm{s}^{2}\right)$, $\bar{a}_{y}(\mathrm{t})$ : maximum acceleration in y direction $\left(\mathrm{m} / \mathrm{s}^{2}\right), \quad \bar{a}_{z}(\mathrm{t})$ : maximum acceleration in z direction $\left(\mathrm{m} \cdot \mathrm{s}^{-2}\right)$.

$A S I=\max \sqrt{\left(\frac{\overline{a_{x}}(t)^{2}}{12}\right)+\left(\frac{\overline{a_{y}}(t)^{2}}{9}\right)^{2}+\left(\frac{\overline{a_{z}}(t)^{2}}{10}\right)^{2}}$

\section{Hybrid Barrier Pendulum System}

According to EN 1317, barriers must achieve crash tests for their eligibility to use on roads. Although full-scale crash tests are a conventional mechanism to reveal the barrier performance, such tests are very costly in terms of the procurement of the required experiment area (creating a collision path, taking safety precautions, etc.), creating the crash mechanism (ensuring the vehicle hit at a certain speed and angle), and cost of each vehicle in repeated experiments. For this reason, in the literature, pendulum and similar systems have been used in the optimization phase instead of full-scale crash tests for the performance analysis of barrier systems. (El-Salakawy et al., 2004; Gabauer et al., 2010; Gierczycka et al., 2015; Mitchell et al., 2010; MorenoPerez et al., 2015; Raj et al., 2020; Yamaguchi et al., 2014).

The hybrid barrier pendulum system consisted of a rigid frame, pendulum rammer, and chains on which the pendulum rammer was suspended. The pendulum rammer was lifted to a certain height and released for free fall. Thus, the same energy can be applied by crashing the barrier at the same speed each time. Besides being more economical than real-time crash tests, the pendulum system is more suitable in terms of work safety and more practical. RHB pendulum system is shown in Fig. 6.

The outer walls of the pendulum rammer were made of a $10 \mathrm{~mm}$ thick steel sheet and the inner part was filled with iron powder and weighs $1500 \mathrm{~kg}$ to represent the TB31 vehicle. The pendulum rammer was suspended on the

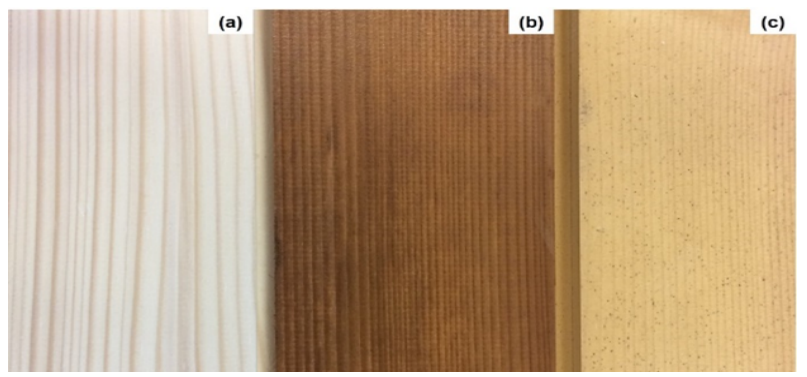

Fig. 5 Non-treated (a), impregnated (b) heat-treated (c) timbers. mainframe with a total of 4 chains, 2 on each side. In this way, it is aimed to keep the weight in the axis during the collision and to prevent lateral oscillations. The total energy of the pendulum in the number 1 position is calculated according to the potential energy equation in Formula 2. In this formula, $E_{p}$ : total potential energy $(J), m$ : weight of the rammer $(\mathrm{kg}), \mathrm{g}$ : gravitational acceleration $\left(\mathrm{m} . \mathrm{s}^{-2}\right)$, h: height of the rammer (m).

$$
E p=m \cdot g \cdot h
$$

According to the law of conservation of energy, the pendulum hammer loses its height, and its potential energy just before colliding with the barrier completely converts into kinetic energy thus, the potential energy of the pendulum rammer at position 1 and kinetic energy at position 2 will be equal. From this point of view, the amount of energy generated on the barriers during the collision is indicated in Fig. 7 according to the containment levels. For the N1 containment level, this energy is specified as $43 \mathrm{~kJ}$. According to Formula 2, it was calculated that the freefall height of the pendulum rammer should be $2.93 \mathrm{~m}$ to attain this energy level.

In summary, our study was based on TB31 acceptance test and N1 normal containment level test criteria. Accordingly, the pendulum rammer weighing 1500 $\mathrm{kg}$ was lifted with the help of a crane mounted on the pendulum system frame so that its center of gravity was $1.73 \mathrm{~m}$. Repeated experiments were carried out by lifting the pendulum rammer to the same height for each experiment and energy of $25.5 \mathrm{~kJ}$ was created on the barrier every time. There is not any information in EN 1317 standard regarding the height of the pendulum rammer from the ground level at the crash point. Within the scope of this study, the average of N1 containment level vehicle types was analyzed, and additionally, in the light of literature studies, this value was predicted to be $50 \mathrm{~cm}$ then the rammer was hung on the pendulum system frame.

\section{Data Supply}

In order to be able to determine the barrier performance regarding EN 1317, the ASI value specified in Formula 1 must be calculated and the above-mentioned $W$ value must be measured. For this purpose, crash tests were carried out by placing the accelerometer device (PCB Piezotronics-350A43) in the center of the gravity of pendulum rammer considering the relevant standard. In addition, two cameras were placed at the points specified in the same standard so that they can capture horizontally (Casio Exilim Pro EX-F1) and from the top (GoPro Hero 5). Reference scales $7.5 \mathrm{~cm}$ in diameter were placed at certain points on the pendulum system to verify measurements obtained from the camera images. Working width (W) measurements were carried out on camera images using the "ImageJ" program.

\section{Renewable Hybrid Barrier Experiment Matrix}

It was estimated that the thickness of the wood material, impregnation, heat treatment and the moisture content of wood and sand would have an effect on the crash performance of RHBs, and in this direction, the 


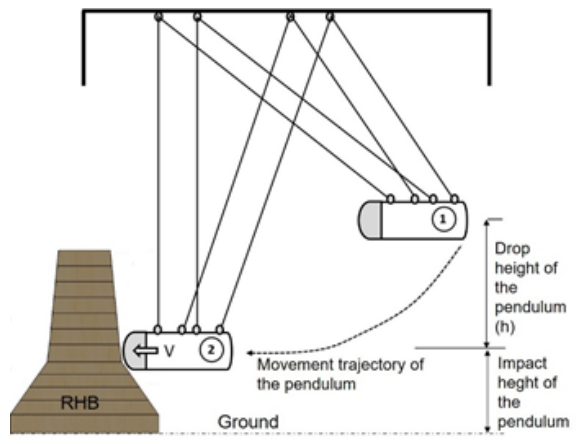

experiment matrix shown in Tab. 1 was created. Within the scope of the study, a total of 36 RHBs were produced with 3 successful repetitions for every 12 types of barriers. An additional experiment was also carried out to observe the crash performance of the connection point.

\section{RESULTS AND DISCUSSION}

Relevant experiments were carried out according to Table 1, and the images of RHBs taken after pendulum crash tests are shown in Fig. 8. All tests were carried out by crashing the pendulum rammer through the middle points of the RHBs except for group D. Differently, in group D, it was carried out at the connection point of adjacent RHBs. The data obtained from the crash tests are presented in Tab. 2 and 3. As can be seen in Fig. 8, the deformation amounts of the wooden parts on the crash surface were generally similar. Approximately five of the timbers on the crash surface were broken or cracked after the crash tests. No deformation occurred in the timbers on the back surfaces of the RHBs. This may indicate that the energy generated by the crash is sufficiently absorbed by sand and wood.

Tab. 2 shows the working width classes revealed considering the test results. In the light of the measurements obtained from the camera images during the pendulum crash tests, it is seen that the RHBs are in the W5-W8 working width range for various test matrix. According to the results in Tab. 2, it is seen that there is no significant change in working width classes with the change of fir timber thickness. These results reveal that the use of $2 \mathrm{~cm}$

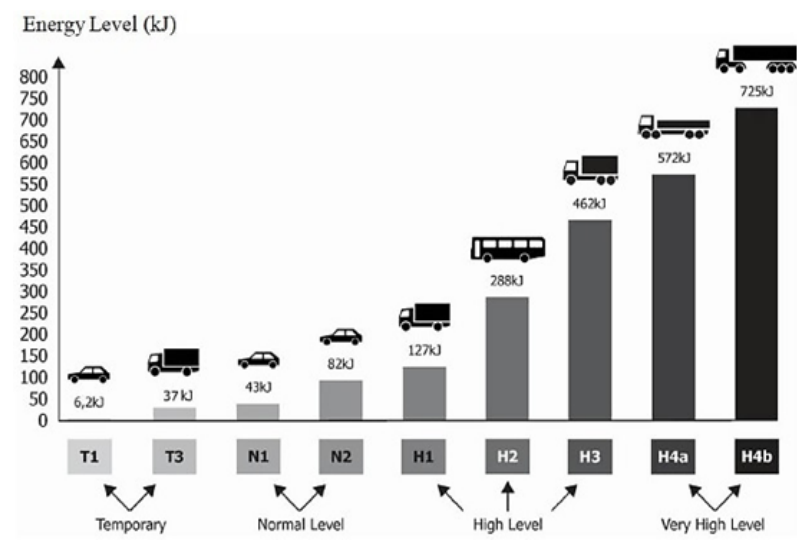

Fig. 7 Classification of containment levels with respect to vehicle types (CEN, 2017) thick timbers will be sufficient, and the use of $4 \mathrm{~cm}$ thick timbers means redundant cost increase.

There is no significant difference between the $A$ and $B$ groups in terms of working width classes. According to the studies in the literature, it is stated that the impregnation process partially improves the mechanical properties of the wood material but does not cause a significant change ( $\mathrm{Li}$ et al., 2020; Percin et al., 2015; Simsek et al., 2010; Taghiyari, 2011). In accordance with the literature, it can be said that the impregnation process does not have a negative effect on the working width of RHBs. Similarly, there is no significant difference between the $A$ and $C$ groups in terms of working width classes. The hydrolysis of hemicelluloses as a result of heat treatment of wood material significantly reduces the mechanical properties (especially shock resistance) of the wood material (Kocaefe et al., 2008; Kucerova et al., 2016; Yang and Liu, 2020). The crash test results reveal that the amount of this expected decrease in resistance after heat treatment is at a negligible level compared to the total resistance of $\mathrm{RHBs}$.

When the non-treated, impregnated, and heattreated samples were evaluated in their self-group, it was observed that the water saturation of the sand and wood material reduced the working width slightly. This situation is thought to be due to the weight of water added to the barriers. It was observed that the working widths of wet RHBs are generally lower than air-dried RHBs. In the literature, it is stated that the mechanical properties of wood increase due to the increase in moisture content and the shock resistance improves (Gerhards, 1982). In accordance with the literature, the increase of the working widths can be explained by the improvement in the shock resistance. The decrease in the working width with the increased moisture is an indication that RHBs will have more effective results in a possible accident, especially in rainy weather. Based on this, it can be said that the use of RHBs in outdoor conditions will be appropriate in terms of traffic safety.

According to the result of the connection point crash test, RHBs are in the W7 working width class specified in EN 1317, and this result is close to other crash tests. From this point of view, it can be said that possible impacts to any points of the RHBs will reveal similar results. Tab. 3 shows the ASI values obtained as a result of using the acceleration data of pendulum crash tests in Formula 1. ASI values in all barrier types were obtained as class $A$ and $B$. In the light of these results, RHBs meet the TB31 acceptance test criteria and it can be said that RHBs will keep the passenger safety within a vehicle at the desired level during an impact. 
Tab. 1 Renewable hybrid barrier experiment matrix.

\begin{tabular}{|c|c|c|c|c|c|}
\hline Groups & Experiment Code & Treatment & $\begin{array}{l}\text { Wood Thickness } \\
(\mathrm{mm})\end{array}$ & $\begin{array}{l}\text { Wood Moisture Content } \\
(\%)\end{array}$ & $\begin{array}{c}\text { Sand Moisture Content } \\
(\%)\end{array}$ \\
\hline \multirow{4}{*}{$\begin{array}{c}A \\
\text { (control) }\end{array}$} & B1D2 & Non-Treated & 20 & Non-Treated & 20 \\
\hline & B1D4 & Non-Treated & 40 & Non-Treated & 40 \\
\hline & B1W2 & Non-Treated & 20 & Non-Treated & 20 \\
\hline & B1W4 & Non-Treated & 40 & Non-Treated & 20 \\
\hline \multirow{5}{*}{$\begin{array}{c}\text { B } \\
\text { (impregnated) }\end{array}$} & B2D2 & Impregnated & 20 & Non-Treated & 40 \\
\hline & B1D2 & Non-Treated & 20 & Non-Treated & 20 \\
\hline & B1D4 & Non-Treated & 40 & Non-Treated & 20 \\
\hline & B1W2 & Non-Treated & 20 & Non-Treated & 40 \\
\hline & B1W4 & Non-Treated & 40 & Non-Treated & 20 \\
\hline \multirow{3}{*}{$\begin{array}{c}\text { C } \\
\text { (heat-treated) }\end{array}$} & B2D2 & Impregnated & 20 & Non-Treated & 20 \\
\hline & B1W2 & Non-Treated & 20 & Non-Treated & 40 \\
\hline & B1W4 & Non-Treated & 40 & Non-Treated & 20 \\
\hline $\mathrm{D}$ (Connection point) & $\mathrm{B} 2 \mathrm{D} 2$ & Impregnated & 20 & Non-Treated & 20 \\
\hline
\end{tabular}

Tab. 2 Working width results of RHBs according to pendulum crash tests.

\begin{tabular}{|c|c|c|c|c|}
\hline \multirow{2}{*}{ Groups } & \multirow{2}{*}{ Experiment Code } & $25 \mathrm{~kJ}$ & $43 \mathrm{~kJ}$ & $43 \mathrm{~kJ}$ \\
\hline & & $W(m)$ & $W(m)$ & W Class \\
\hline \multirow{4}{*}{$\begin{array}{c}A \\
\text { (control) }\end{array}$} & B1D2 & $0.87(0.15)$ & 1.46 & W5 \\
\hline & B1D4 & $1.08(0.04)$ & 1.83 & W6 \\
\hline & B1W2 & $1.09(0.01)$ & 1.83 & W6 \\
\hline & B1W4 & $1.11(0.07)$ & 1.88 & W6 \\
\hline \multirow{4}{*}{$\begin{array}{c}\text { B } \\
\text { (impregnated) }\end{array}$} & B2D2 & $1.03(0.07)$ & 1.74 & W6 \\
\hline & B2D4 & $1.09(0.06)$ & 1.83 & W6 \\
\hline & B2W2 & $1.07(0.01)$ & 1.80 & w6 \\
\hline & B2W4 & $1.04(0.01)$ & 1.76 & W6 \\
\hline \multirow{4}{*}{$\begin{array}{c}\text { C } \\
\text { (heat-treated) }\end{array}$} & B3D2 & $1.12(0.04)$ & 1.89 & W6 \\
\hline & B3D4 & $1.14(0.05)$ & 1.92 & W6 \\
\hline & B3W2 & $1.08(0.04)$ & 1.83 & W6 \\
\hline & B3W4 & $1.09(0.06)$ & 1.83 & W6 \\
\hline D (connection point) & B4D4 & $1.34(0.00)$ & 2.26 & W7 \\
\hline evalues in parenthesis are & d deviations. & & & \\
\hline
\end{tabular}

Tab. 3 ASI classes of RHBs according to pendulum crash tests.

\begin{tabular}{|c|c|c|c|c|c|c|}
\hline \multirow[b]{2}{*}{ Groups } & RHB Code & $25.5 \mathrm{~kJ}$ & $25.5 \mathrm{~kJ}$ & $43 \mathrm{~kJ}$ & $43 \mathrm{~kJ}$ & $43 \mathrm{~kJ}$ \\
\hline & $\begin{array}{l}\text { Deceleration } \\
\left(\mathrm{m} \cdot \mathrm{s}^{-2}\right)\end{array}$ & ASI Values & ASI Class & $\begin{array}{l}\text { Deceleration } \\
\left(\mathrm{m} \cdot \mathrm{s}^{-2}\right)\end{array}$ & ASI Values & ASI Class \\
\hline \multirow{4}{*}{$\begin{array}{c}\text { A } \\
\text { (control) }\end{array}$} & B1D2 & $5.80(0.98)$ & $0.48(0.06)$ & 9.78 & 0.82 & A \\
\hline & B1D4 & $5.36(0.90)$ & $0.45(0.06)$ & 9.04 & 0.75 & $A$ \\
\hline & B1W2 & $7.49(0.60)$ & $0.63(0.03)$ & 12.64 & 1.05 & B \\
\hline & B1W4 & $7.23(0.79)$ & $0.60(0.04)$ & 12.20 & 1.02 & $\mathrm{~B}$ \\
\hline \multirow{4}{*}{$\begin{array}{c}\text { B } \\
\text { (impregnated) }\end{array}$} & B2D2 & $6.97(0.60)$ & $0.58(0.03)$ & 11.75 & 0.97 & $A$ \\
\hline & B2D4 & $6.32(0.81)$ & $0.53(0.04)$ & 10.66 & 0.89 & $A$ \\
\hline & B2W2 & $6.45(1.17)$ & $0.54(0.07)$ & 10.88 & 0.91 & $A$ \\
\hline & B2W4 & $6.58(1.26)$ & $0.55(0.07)$ & 11.10 & 0.93 & A \\
\hline \multirow{4}{*}{$\begin{array}{c}\text { C } \\
\text { (heat-treated) }\end{array}$} & B3D2 & $6.58(0.60)$ & $0.55(0.07)$ & 11.10 & 0.93 & A \\
\hline & B3D4 & $7.36(1.26)$ & $0.61(0.07)$ & 12.42 & 1.04 & B \\
\hline & B3W2 & $6.71(0.45)$ & $0.56(0.02)$ & 11.31 & 0.94 & $A$ \\
\hline & B3W4 & $6.45(0.39)$ & $0.54(0.02)$ & 10.88 & 0.91 & A \\
\hline $\mathrm{D}$ (connection point) & B4D4 & $5.67(0.00)$ & $0.47(0.00)$ & 9.56 & 0.83 & $\mathrm{~A}$ \\
\hline
\end{tabular}


According to the crash test results of group $\mathrm{A}$ RHBs, ASI classes of wet RHBs are lower than air-dried RHBs. The increase in moisture did not cause a significant difference in $\mathrm{RHBs}$ ( $\mathrm{B}, \mathrm{C}$ groups) produced with impregnated and heat-treated fir timbers as in group A. According to Tab. 3 timber thickness, heat treatment and impregnation do not significantly affect the ASI value. It can be said that it is appropriate and adequate to use fir timber $2 \mathrm{~cm}$ in thickness to diminish the cost in the production of RHBs. In addition, it is observed that wood protection methods, which are vital for extending the service life of RHBs to be used in outdoor conditions, do not affect the crash performance of RHBs negatively. Group D RHBs are generally in the same ASI class with other RHB types. This result reveals that RHBs will have sufficient performance against possible impacts to any point. In the light of the results presented in Tab. 2 and 3 , considering the cost, crash performance, and service life criteria, it can be said that the most suitable RHBs should be $2 \mathrm{~cm}$ in thickness, impregnated, or heat-treated.
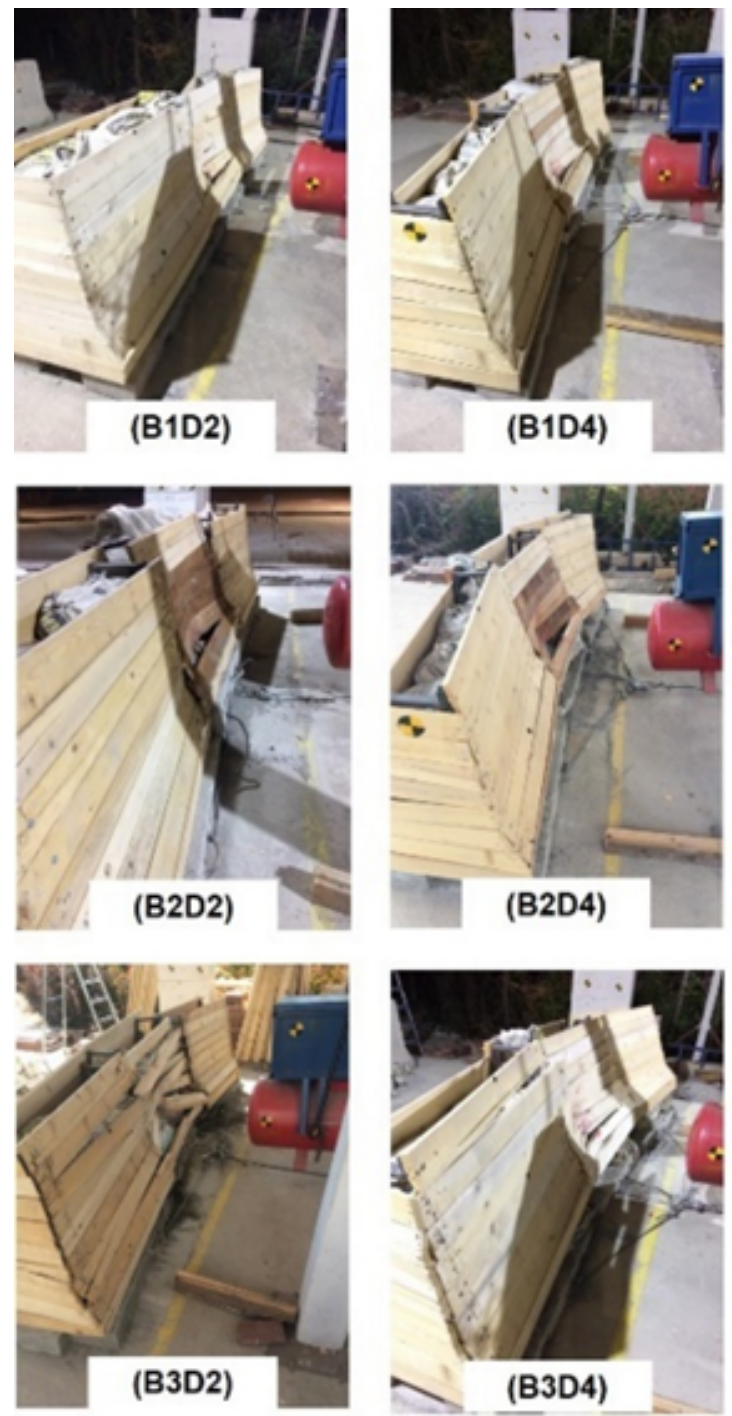

\section{CONCLUDING REMARKS}

The use of wood material and sand which both have high shock absorption increase the impact absorption of RHBs significantly and therefore, it was concluded that damage to the vehicle and the possibility of casualties of the passengers in the vehicle after the collision will reduce.

The ability to re-use sand after crashes repeatedly due to its un-deformable structure, deformation of a limited number of timber and rapid repair / rehabilitation process due to being demountable of each timber parts can be regarded as significant advantages in terms of both decreasing the cost and preventing traffic restraints. Oncoming vehicle lights during night drive are one of the important matters in terms of traffic safety. By placing plants that can remain green for four seasons on the top of the $\mathrm{RHBs}$, the oncoming vehicle lights will be prevented during night driving pretending as anti-glare systems. In this way, it is aimed to contribute to both aesthetic appearance and increase traffic safety.
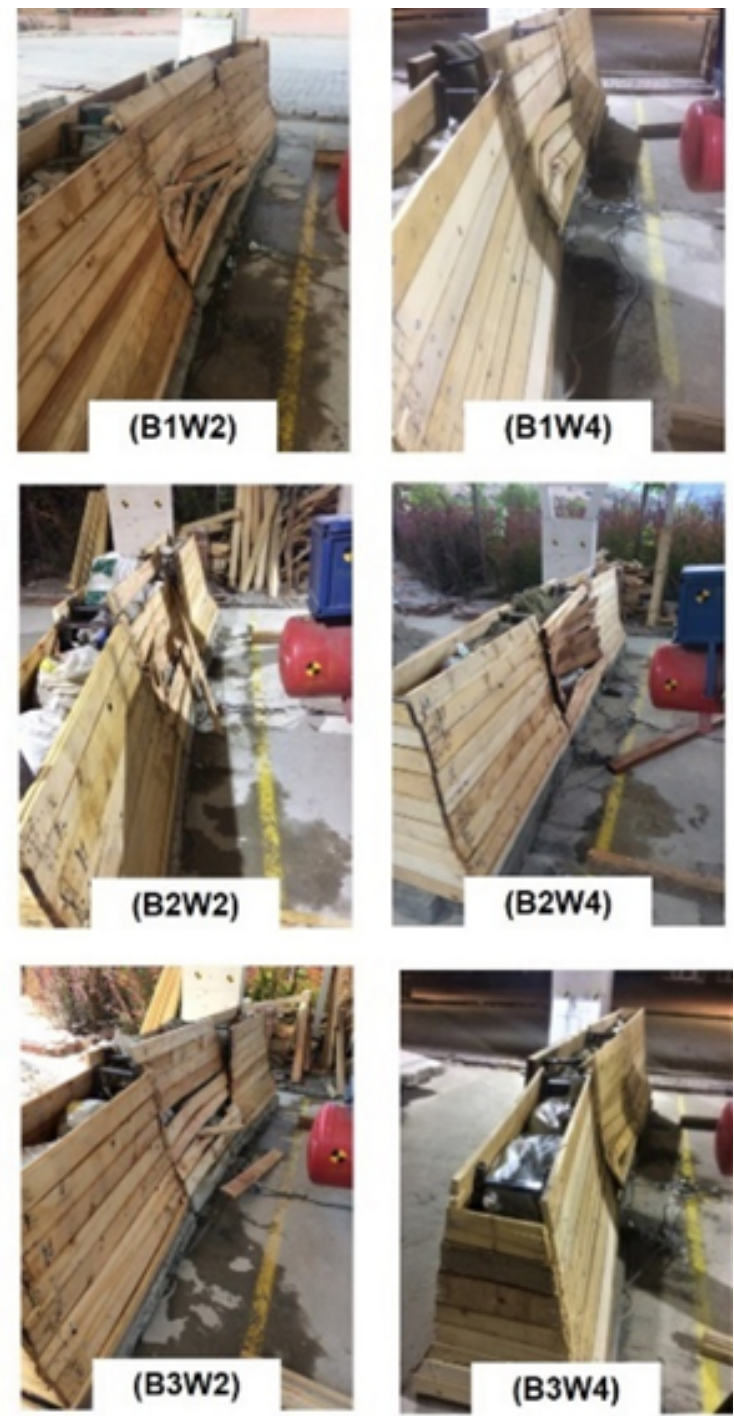

Fig. 8 Images of RHBs after the pendulum crash tests. 
Since the sound absorption coefficient of wood material is higher than steel and concrete material, It is thought that the use of RHBs, especially in urban areas, will contribute to the reduction of traffic noise.

RHBs are designed in F-shape barrier dimensions in order to be compared with an existing barrier type. After the optimization is achieved, it is recommended to create different designs carrying out the performance tests in future studies. In the light of the results of the study, the optimum wood timber thickness was determined as $2 \mathrm{~cm}$ regarding TB 31 test criteria. It is proposed that the crash tests for different wood species, timber thickness, and/or barrier dimensions should carry out in future studies. This study can serve as the basis for the next step, real-time real crash tests. Since the study includes an interdisciplinary subject, it is thought that it will inspire different studies.

\section{ACKNOWLEDGEMENTS}

This study was supported by TUBITAK (The Scientific and Technological Research Council of Turkey). Project number: 118M753.

\section{AUTHORSHIP CONTRIBUTION}

Project Idea: HIY

Database: HIY, HY, EB

Processing: HIY, HY, EB

Analysis: HIY, HY, EB, SO, AOA

Writing: HIY, HY, EB

Review: HIY, HY, EB, SO, AOA.

\section{REFERENCES}

AASHTO. Roadside design guide. American Association of State Highway and Transportation Officials, v. 4, p. 01-29, 2011.

BHATTI, A. Q. Falling-weight impact response for prototype RC type rock-shed with sand cushion. Materials and Structures / Materiaux et Constructions, v. 48, n. 11, p. 3367-3375, 2015.

BIRINCI, E.; YORUR, H.; YUMRUTAS, H. I.; DUYAR, A. Evaluation of renewable hybrid barriers in terms of carbon emission with concrete and steel barriers. Forestist, v. 1, n. 1, 2021.

BOROVINSEK, $M_{\text {: }}$ VSENJAK, $M_{\text {: }}$ ULBIN, $M_{\text {: }}$ REN, Z. Simulation of crash tests for high containment levels of road safety barriers. Engineering Failure Analysis, v. 14, n. 8, p. 1711-1718, 2007.

CHELL, J.; BRANDANI, C. E.; FRASCHETTI, S.; CHAKRAVERTY, J.; CAMOMILLA, V. Limitations of the european barrier crash testing regulation relating to occupant safety. Accident Analysis and Prevention, v. 133, p. 105239, 2019.

CHAIN, S. C.; TAN, B. C. V.; SARMA, A. Reprint of: Projectile penetration into dand: relative density of sand and projectile nose shape and mass. International Journal of Impact Engineering, v. 105, p. 80-88, 2017.

DANEK, W.; PAWLAK, M. Charpy impact testing machine in modeling of vehicle frontal crash with street lights. Springer Proceedings in Mathematics and Statistics, v. 249, p. 73-84, 2018.

DAVIDS, W. G.; BOTTING, J. K.; PETERSON, M. Development and structural testing of a composite-reinforced timber highway guardrail. Construction and Building Materials, v. 20, n. 9, p. 733-743, 2006.

DAVIES, H. From trackways to motorways: 5000 years of highway history, Tempus Publishing, 2006. 192p.
EL-SALAKWY, E: MASMOUDI, R: BENMOKRANE, B; BRIERE, F; DESGAGNE, $G$. Pendulum impacts into concrete bridge barriers reinforced with glass fibre reinforced polymer composite bars. Canadian Journal of Civil Engineering, v. 31 n. 4, p. 539-552, 2004.

ELVIK, R.; VAA, T.; HOYE, A.; SORENSEN, M. The handbook of road safety measures, Emerald Group Publishing Limited, 2009. 1124p.

EUROPEAN COMISSION. Road Safety: Data show improvements in 2017 but renewed efforts are needed for further substantial progress. Available at: https://ec.europa.eu/transport/news/2018-04-10-road-safety-datashow-improvements_en. Accessed in: 25 November 2020.

GABAUER, D. J.; KUSANO, K. D.; MARZOUGUI, D.; OPIELA, K.; HARGRAVE, M.; GABLER, H. C. Pendulum testing as a means of assessing the crash performance of longitudinal barrier with minor damage. International Journal of Impact Engineering, v. 37, n. 11, p. 1121-1137, 2010.

GERHARDS, C. C. Effects of moisture content and temperature on the mechanical properties of wood: an analysis of immediate effects. Wood and Fiber Science, v. 14, n. 1, p. 4-36, 1982.

GIERCZYCKA, D.; WATSON, B.; CRONIN, D. Investigation of occupant arm position and door properties on thorax kinematics in side impact crash scenarios-comparison of ATD and human models. International Journal of Crashworthiness, v. 20, n. 3, p. 242-269, 2015.

GRZEBIETA, R. H.; ZOU, R.; JIANG, T.; CAREY, A. Roadside hazard and barrier crashworthiness issues confronting vehicle and barrier manufacturers and government regulators. Publisher National Highway Traffic Safety Administration, v. 3, p. 24, 2005.

KASZYNSKI, W. The American highway: the history and culture of roads in the United States, McFarland \& Company, 2012. 237p.

KOCAEFE, D.; PONCSAK, S.; BOLUK, Y. Effect of thermal treatment on the chemical composition and mechanical properties of birch and aspen. BioResources, v. 3, n. 2, p. 517-537, 2008.

KOLLMANN, F. F. P; KUENZI, E. W. Principles of wood science and technology, Springer-Verlag Berlin Heidelberg, 1968. 592p.

KUCEROVA, V.; LAGANA, R.; VYBOHOVA, E.; HYROSOVA, T. The effect of chemical changes during heat treatment on the color and mechanical properties of fir wood. BioResources, v. 11, n. 4, p. 9079-9094, 2016.

LI, P.; ZHANG, Y.; ZUO, Y.; WU, Y.; YUAN, G.; LU, J. Comparison of silicate impregnation methods to reinforce Chinese fir wood. Holzforschung, v.75, n.2. p. $126-137,2020$.

MITCHELL, G.; STRAHOTA, M. T.; GOKANI, V.; PICON, R.; YANG, S.; CLINGER, R. E. WILLIAMSON, E. B. Performance of retrofit highway barriers with mechanical anchors. ACI Structural Journal, v. 107, n. 4, n. 381-389, 2010.

MORENO-PEREZ, F.; BARROSO, A.; CANAS, J.; PARIS, F. Influence of the size and depth of a circumferential notch on the impact behaviour of streetlights. A passive-safety concept. Engineering Failure Analysis, v. 53, p. 15-23, 2015.

ORNEK, M.; ATAHAN, A. O.; TUREDI, Y., ERDEM, M. M.; BUYUK, M. Soil based design of highway guardrail post depths using pendulum impact tests. Acta Geotechnica Slovenica, v. 16, n. 2, p. 77-89, 2019.

PAROBEK, J.; PALUS, H.; MORAVCIK, M.; KOVALCIK, M.; DZIAN, M.; MURGAS, V.; SIMO-SVRCEK, S. Changes in carbon balance of harvested wood products resulting from different wood utilization scenarios. Forests, v. 10, n. 7, p. 1-13, 2019.

PERCIN, O.; SOFUOGLU, S. D.; UZUN, O. Effects of boron impregnation and heat treatment on some mechanical properties of oak (Quercus petraea Liebl.) wood. BioResources, v. 10, n. 3, p. 3963-3978, 2015.

PILIA, F.; MALTINTI, F.; ANNUNZIATA, F. Preliminary results on a new safety road barrier made completely of wood. Environmental Semeiotics, v. 5, n. 2, p. 11-23, 2012

PORAN, C. J.; RODRIGUEZ, J. A. Finite element analysis of impact behavior of sand. Soils and Foundations, v. 32, n. 4, p. 68-80, 1992

RAJ, A.; NAGARAJAN, P.; PALLIKARA, S. A. Application of fiber-reinforced rubcrete for crash barriers. Journal of Materials in Civil Engineering, v. 32, n. 12, p. 04020358, 2020.

SABET, A. R.; BEHESHTY, M. H.; RAHIMI, H. Experimental study of sharptipped projectile perforation of gfrp plates containing sand filler under high velocity impact and quasi-static loadings. Polymer Composites, v. 30, n. 10 , p. 1497-1509, 2009

SIMSEK, H.; BAYSAL, E.; PEKER, H. Some mechanical properties and decay resistance of wood impregnated with environmentally-friendly borates," Construction and Building Materials, v. 24, n. 11, p. 2279-2284, 2010.

HO, T. S.; MASUYA, H. Finite element analysis of the dynamic behavior of sand-filled geocells subjected to impact load by rockfall. International Journal of Erosion Control Engineering, v. 6, n. 1, p. 1-12, 2013.

TAGHIYARI, H. R. Study on the effect of nano-silver impregnation on mechanical properties of heat-treated Populus nigra. Wood Science and Technology, v. 45, n. 2, p. 399-404, 2011. 
TENG, T. L.; LIANG, C. C. HSU, C. Y: SHIH, C. J.; TRAN, T. T. Impact performance of $\mathrm{W}$-beam guardrail supported by different shaped posts. International Journal of Mechanical Engineering and Applications, v. 4, n 2, p. 59-64, 2016

TOR, O.; BIRINCI, E.; HU, L.; CHEN, C. Effects of pilot hole diameter and depth on screw driving torques in plywood. BioResources, v. 15, n. 4, p. 8121-8132, 2020.

TUDOR, E. M.; DETTENDORFER, A.; KAIN, G.; BARBU, M. C.; REH, R. KRISTAK, L. Sound-absorption coefficient of bark-based insulation panels Polymers, v. 12 , n. 5, p. 1-11, 2020

YAMAGUCHI, G. T.; DAINTY, D.; LAM, T.; WATSON, H. Performance of certified climbing helmets during simulated climbing falls. Journal of Testing and Evaluation, v. 42, n. 5, p. 1257-1277, 2014.

YANG, L.; LIU, H. H. Effect of a combination of moderate-temperature heat treatment and subsequent wax impregnation on wood hygroscopicity dimensional stability, and mechanical properties. Forests, v. 11, n. 9, p. 1-9, 2020
YANG, X.; TANG, X.; MA, L.; SUN, Y. Sound insulation performance of structural wood wall integrated with wood plastic composite, Journal of Bioresources and Bioproducts, v. 4, n. 2, p. 111-118, 2019.

YEGINOBALI, A.; ATAHAN, A. O.; GOZEN, A. Concrete barriers (guardrails), Ankara, 2011

YORUR, H.; BIRINCI, E.; GUNAY, M. N.; TOR, O. Effects of factors on direct screw withdrawal resistance in medium density fiberboard and particleboard. Maderas. Ciencia Y Tecnología, v 22, n. 3, p. 375$384,2020$.

YUMRUTAS, H. I.; YORUR, H. Hybrid road barrier design as aesthetic safety feature and urban furniture. International Journal of System Modeling and Simulation, v. 2, n. 2, p. 23-26, 2017.

ZHANG, X.; CHEN, J.; DIAS, A. C.; YANG, H. Improving carbon stock estimates for in-use harvested wood products by linking production and consumption - a global case study. Environmental Science and Technology, v. 54, n. 5, p. 2565-2574, 2020. 